\title{
Winter Food Habits of Ravens on the Arctic Slope of Alaska
}

\author{
STANLEY A. TEMPLE ${ }^{1}$
}

\begin{abstract}
Analysis of 684 pellets from a winter roost of ravens (Corvus corax) at Umiat, Alaska, indicated that during the winters of 1966 and 1967 ravens obtained half of their energy income through predation and half through scavenging. Microtine rodents provided the bulk of the predatory half of the raven's diet, whereas carcasses of caribon (Rangifer arcticus) and ptarmigan (Lagopus spp.) were the items most often scavenged. The relative abundance of prey species in pellets suggests that ravens spent most of their time hunting in upland habitats on the tundra.
\end{abstract}

RÉSUMÉ. Habitudes alimentaires hivernales des corbeaux sur le versant arctique de l'Alaska. L'analyse de 684 boulettes d'un perchoir de corbeaux (Corvus corax) à Umiat, Alaska, indique qu'au cours des hivers de 1966 et 1967, les corbeaux obtenaient la moitié de leur énergie par la prédation et la moitié par la vidange. Les petits rongeurs fournissaient le gros de la moitié "prédatoire" du régime du corbeau alors que les carcasses de caribous (Rangifer arcticus) et de lagopèdes (Lagopus spp.) étaient les éléments les plus souvent vidangés. L'abondance relative des différentes espèces de proies dans les boulettes suggère que les corbeaux passent la plus grande partie de leur temps de chasse dans des habitats de hautes-terres sur la toundra.

\begin{abstract}
РЕЗЮМЕ. Зимний рачион питания воронов Арктического Склона Аляеки. Анализ 684 погадок, собранных на вимнем местообитании воронов (Corvus corax) в районе Умиата (Аляска), показал, что зимой 1966 и 1967 гт. половину своећ потребности в энергии эти птицы покрывали аа счёт продуктов охоты, и половину - за счёт потребления падали. Основная часть зимнего рациона воронов, доставляемая охотой, была представлена мелкими трызунами (мытами), тогда как иеточником второй половины этого рациона чаще всего были трупы карибу (Rangifer arcticus) и белых куропаток (Lagopus sp.). Относительно большое содержание продуктов охоты в погадках позволяет предполатать, что большую часть своего времени вороны проводили в охоте на возвыпенных местообитаниях тундры.
\end{abstract}

\section{INTRODUCTION}

Few regions of North America experience as severe a winter climate as the tundra of the Arctic Slope in northern Alaska, where subfreezing weather persists from early October until mid-May, and temperatures may drop to $-55^{\circ} \mathrm{C}$. Adding to the rigours of winter on the Arctic Slope, the sun stays below the horizon from late November until early January. As would be expected, only the hardiest of birds can over-winter in this climate, and according to Kessel and Cade (1958) only 5 species are regular winter residents: 2 ptarmigan (Lagopus mutatus and L. lagopus), the gyrfalcon (Falco rusticolus), the snowy owl (Nyctea scandiaca), and the raven (Corvus corax). In addition to being the only passerine, the raven stands out as being the only species not especially adapted for arctic life. The biological adaptations that ravens must possess to withstand the arctic winter are

1Section of Ecology and Systematics, Division of Biological Sciences, Cornell University, Ithaca, New York, U.S.A. 
manifold. Scholander et al. (1950) and Veghte and Herreid (1965) have demonstrated how the raven's physiology and anatomy allow for its existence under arctic conditions, but little is known of the ecological and behavioural adjustments that ravens have made. Obtaining food is probably the most crucial problem facing ravens during the arctic winter, and most of their time must be spent foraging during the brief daylight hours. Only scattered observations have been made of the winter diet of ravens in the North American Arctic (Sutton 1932; Bent 1946; Harper 1958), and these are neither quantitative nor extensive in scope. The purposes of this paper are to present an analysis of the winter food habits of ravens on Alaska's Arctic Slope and to discuss the ecological and behavioural adjustments suggested by their diet.

\section{MATERIALS AND METHODS}

At the deserted town of Umiat, Alaska $\left(152^{\circ} 08^{\prime}\right.$ N., $69^{\circ} 22^{\prime}$ W.), centrally located in the interior of the Arctic Slope, a small flock of ravens used the rafters of an abandoned hangar as a roost during the winters of 1966 and 1967. Bush pilots who regularly stopped to refuel at Umiat during the winter said that approximately 10 ravens roosted in the hangar from early November until mid-March.

Ravens share with several other groups of predaceous birds the habit of regurgitating pellets containing undigested portions of their food. Like the owls, ravens do not digest bony material, and their pellets often contain essentially complete skeletal remains of their prey in addition to fur, feathers, and other more typical pellet materials. Because of the protection afforded by the hangar, raven pellets that accumulated on its floor were remarkably well preserved. During the early summers of 1967 and 1968 individual pellets were collected at this roost and wrapped in tissue paper for later analysis. The contents of these pellets were analysed using procedures described by Errington (1930). Items such as skeletal parts, fur and feathers in each pellet were identified to the genus or species level by comparison with a reference collection of museum specimens and by using taxonomic keys (Bee and Hall 1956; Hall and Kelson 1959). When possible, I also estimated from skeletal parts the minimum number of individuals of each prey species contained in each pellet.

\section{RESULTS AND DISCUSSION}

The results of an analysis of 684 pellets are summarized in Table 1. These data show clearly that the raven is both a predator and a scavenger. It is, of course, impossible to know exactly which items in the pellets resulted from predation and which from scavenging, consequently some decisions had to be made as to what was actually captured or scavenged. Complete skeletal remains of small mammals and passerines were present in pellets, indicating that ravens consumed these items whole and most probably captured them alive. Furthermore ravens were often seen hunting small rodents in the Umiat area during the summer months. On the other hand, items such as the caribou, moose and fox could not possibly have been killed by ravens, and undoubtedly represent the results of scavenging at predator kills or carcasses left by hunters. 
TABLE 1. Analysis of 684 pellets from a winter raven roost at Umiat, Alaska.

\begin{tabular}{lcc}
\hline Food item & $\begin{array}{c}\text { No. of pellets } \\
\text { containing item }\end{array}$ & $\begin{array}{c}\text { Per cent frequency } \\
\text { of occurrence* }\end{array}$ \\
\hline From PREDATion: & & \\
Voles, Microtus spp & 158 & 23.0 \\
Brown lemming, Lemmus trimucronatus & 149 & 21.7 \\
Collared lemming, Dicrostonyx groenlandicus & 92 & 13.4 \\
Red-backed vole, Clethrionomys rutilis & 87 & 12.7 \\
Unidentified microtines & 24 & 3.5 \\
Shrews, Sorex spp & 18 & 1.6 \\
Ermine, Mustela erminea & 7 & 0.1 \\
Least Weasel, Mustela rixosa & 1 & 0.7 \\
Unidentified small birds & 5 & \\
From SCAvENGING: & & 1.9 \\
Hare, Lepus spp. & 13 & 37.2 \\
Caribou, Rangifer arcticus & 255 & 5.9 \\
Moose, Alces alces & 41 & 0.4 \\
Red fox, Vulpes fulva & 3 & 39.1 \\
Ptarmigan, Lagopus spp. & 268 & 7.1 \\
Vegetable matter & 49 & 9.2 \\
Garbage & 63 & 10.8 \\
Eggshell & 74 & 2.3 \\
Other & 16 & \\
\hline
\end{tabular}

*Calculated as: no, of pellets containing item/total pellets.

Certain food items such as hare and ptarmigan are at least potentially within the predatory capabilities of a raven. However, on the basis of pellet remains, I believe that these foods were probably scavenged from predator kills. A single hare or ptarmigan would provide more food than a raven could consume in one meal, yet in my analysis, only infrequently was a pellet composed entirely of either item, a fact that suggests that ravens did not take a full meal of ptarmigan or hare and were forced to seek additional food. Also, the skeletal remains of ptarmigan and hare in the pellets indicated that the most frequently consumed portions of the body were the lower legs and feet or head and neck. Bump et al. (1947) found in their study of grouse that these were the portions most often left behind by large predators, in this case a fox, wolf, gyrfalcon, or owl. Sutton's (1932) observations in the eastern North American Arctic support this conclusion for he never saw ravens chase either ptarmigan or hare even when the opportunity arose.

While the town of Umiat is usually deserted, field parties of researchers and hunters do occasionally use the site as a temporary camp, and the garbage portion of the ravens' diet undoubtedly represents items picked up at the local dump. An amazing array of objects such as cellophane wrappers, aluminum foil, butchered bones, cigarette butts, cardboard and styrofoam were found in pellets. The occurrence of eggshell fragments in pellets is, at least in part, also the result of scavenging at the dump. A sample of shell found in a pellet proved, upon microscopic examination of its pore structure, to be from a domestic hen (Gallus gallus).

It is interesting to know what portions of the raven's energy intake are derived from predation and from scavenging. Unfortunately, it is difficult to answer this question directly from pellet remains as it is impossible to know how much of a scavenged food item was actually consumed. However, an approximation can be 
made by employing known facts about the raven's metabolism in conjunction with dietary information.

Scholander $e$ t al. (1950) and Veghte and Herreid (1965) found that the standard metabolic rate of a cold-adapted raven was $92 \mathrm{kcal} /$ day at ambient temperatures below freezing. As an approximation, the active metabolic rate of a bird is double its standard or resting metabolic rate (King and Farner 1961), so that the net energy consumed by an active raven is about $184 \mathrm{kcal} / \mathrm{day}$. Birds lose about 40 per cent of the energy that they ingest as food through fecal and pellet waste, urinary waste, and heat losses (King and Farner 1961). To obtain the $184 \mathrm{kcal}$ of net energy per day needed for survival, a raven must therefore ingest about $309 \mathrm{kcal}$ of gross energy per day in food.

Observation of captive ravens by the author showed that on the average one pellet was ejected each day if the bird's food contained even a small quantity of undigestible matter. Assuming that each pellet represents the undigested remains of a normal daily intake of food, then the 684 pellets analysed represent a total of about $118,656 \mathrm{kcal}$ of gross energy consumed as food by the ravens (684 days $\times 309 \mathrm{kcal} /$ day).

In the case of the ravens, it is possible to calculate how much energy was consumed as a result of the predatory portion of the diet since whole animals were ingested. Table 2 presents calculations of the total amount of gross energy the ravens derived as a result of predation. From these calculations, the total gross energy intake from preying is equal to about $60,893 \mathrm{kcal}$, roughly half of the total gross energy input represented in the pellet collection. It is apparent that the ravens around Umiat function energetically as half predators and half scavengers during the arctic winter. Looking at the raven's relative trophic position in another way, 22 per cent of all pellets were composed entirely of items obtained by predation while 30 per cent were composed entirely of scavenged items; the remaining 48 per cent were mixed. Once again, equally divided roles as predator and scavenger are suggested.

TABLE 2. Analysis of gross energy obtained by ravens through predation based on analysis of 684 pellets.

\begin{tabular}{lccrr}
\hline \multicolumn{1}{c}{ Food item } & $\begin{array}{c}\text { Minimum } \\
\text { individuals } \\
\text { represented }\end{array}$ & $\begin{array}{c}\text { Weight class } \\
\text { (g/individual) }\end{array}$ & $\begin{array}{c}\text { Gross } \\
\text { energy } \\
\text { content } \\
\text { (kcal/g) } \dagger\end{array}$ & $\begin{array}{c}\text { Total } \\
\text { gross } \\
\text { energy } \\
\text { (kcal) }\end{array}$ \\
\hline Microtus spp & 283 & 35 & 1.4 & 13,867 \\
Lemmus trimucronatus & 239 & 80 & 1.4 & 26,768 \\
Dicrostonyx groenlandicus & 142 & 60 & 1.4 & 11,928 \\
Clethrionomys rutilis & 125 & 30 & 1.4 & 5,250 \\
Unidentified microtines & 23 & 35 & 1.4 & 1,150 \\
Sorex spp & 18 & 25 & 1.4 & 630 \\
Mustela erminea & 7 & 100 & 1.4 & 980 \\
M. rixosa & 1 & 50 & 1.4 & 70 \\
Unidentified small birds & 5 & 25 & 2.0 & 250 \\
\hline \multicolumn{1}{c}{ Total } & 843 & & & 60,893 \\
\hline
\end{tabular}

*From Bee and Hall (1956) and museum specimens; †For mammals, from Golley (1961), for birds, from King and Farner (1961); †Calculated as: Individuals $\times$ weight class $\times$ gross energy content. 
During the summers of 1967 and 1968, 10 standard 300-metre traplines were operated in various habitats near Umiat. Since the abundance of small mammals did not change significantly during those two summers, it will be assumed that the abundance also remained unchanged during the intervening winter. The results of this 2-year trapping effort expressed as relative population densities are given in Table 3. From these figures and the percent frequency of occurrence of small mammals in raven pellets, it is possible to make some inferences about the ecological aspects of raven predation. If the available prey are ranked in decreasing abundance and compared with the data on occurrence in pellets, a perfect rank correlation is found; the most abundant prey, Microtus, was taken most often while the least abundant, Mustela, was taken only infrequently. The trapping data indicate that Microtus were six times as abundant as any other small mammal, though they occurred in pellets only slightly more often than Lemmus. The remaining small mammals, on the other hand, were taken approximately in proportion to their abundance in the Umiat area.

TABLE 3. Comparison of prey abundance and frequency of occurrence in pellets

\begin{tabular}{lcc}
\hline \multicolumn{1}{c}{ Food item } & $\begin{array}{c}\text { Per cent relative } \\
\text { abundance* }\end{array}$ & $\begin{array}{c}\text { Per cent relative } \\
\text { frequency of } \\
\text { occurrance in pellets }\end{array}$ \\
\hline Microtus spp. & 69.4 & 30.9 \\
Lemmus trimucronatus & 11.7 & 29.2 \\
Dicrostonyx groenlandicus & 7.3 & 18.0 \\
Clethrionomys rutilis & 7.3 & 17.1 \\
Sorrex spp. & 3.6 & 3.5 \\
Mustela spp. & 0.7 & 1.3 \\
\hline \multicolumn{1}{c}{ Total } & 100.0 & 100.0 \\
\hline
\end{tabular}

*Percentage of total mammals trapped.

A brief review of the habitats occupied by the raven's potential prey suggests an explanation for this apparent discrepancy. Bee and Hall (1956) in their analysis of the mammal populations near Umiat concluded that, on a habitat basis, the two voles (Microtus miurus and $M$. oeconomus) were restricted primarily to the low, wet riparian areas along the Colville River, whereas the other forms all preferred upland habitats on the slopes or ridges above the valley. Because snow accumulates to considerable depths in the low-lying areas, Microtus were, no doubt, somewhat difficult for ravens to hunt. On the other hand, the snow is usually blown off the ridges and slopes so that hunting small rodents would be considerably easier there. It is perhaps for this reason that ravens did not or could not exploit the abundant populations of Microtus in low-lying areas.

These data to some extent conflict with other reports on the winter diets of ravens in the Arctic. The only detailed accounts (Sutton 1932; Podkovyrkin 1953; Koshkina and Kishchinski 1958) give the impression that ravens are primarily scavengers, living off the remains of predator kills, other carcasses and human wastes. These studies were somewhat biased, however, since they were done near large centres of human activity. While many factors may influence the diet 
of local populations of ravens, and considerable regional variation must certainly exist in such an opportunistic species, my data indicate that, at least on the Arctic Slope of Alaska where human activity is minimal, the raven is considerably more predatory in its winter food habits than previously supposed.

\section{ACKNOWLEDGEMENTS}

This work was sponsored by The Arctic Institute of North America with the approval and financial support of the Office of Naval Research under contract N00014-70-A-0219-0001 (subcontract ONR-391) to Dr. Tom J. Cade, Cornell University. The assistance of Barbara $\mathrm{L}$. Temple and students in the vertebrate zoology course at Cornell University in preparing pellets for analysis is gratefully acknowledged.

\section{REFERENCES}

BEE, J. W. and E. R. HALl. 1956. Mammals of Northern Alaska. University of Kansas Museum of Natural History Miscellaneous Publications, No. 8. 309 pp.

BENT, A. C. 1946. Life histories of North American jays, crows and titmice. United States National Museum Bulletin, 191: 183-201.

BUMP, G., R. W. DARROW, F. C. EDMINSTER, W. F. CRISSEY. 1947. The Ruffed Grouse: Life History, Propagation, Management. Albany: New York State Conservation Department. $915 \mathrm{pp}$.

ERRINGTON, P. C. 1930. The pellet analysis method of raptor food habit study. Condor, 32: 292-96.

GOLLEY, F. B. 1961. Energy values of ecological materials. Ecology, 42: 581-84.

HALl, E. R. and K. R. Kelson. 1959. The Mammals of North America. New York: The Ronald Press. 1083 pp.

HARper, F. 1958. Birds of the Ungava Peninsula. University of Kansas Museum of Natural History Miscellaneous Publications, No. 17.171 pp.

KESSEL, B. and T. J. CADE. 1958. Birds of the Colville River, Northern Alaska. Biological Papers of the University of Alaska, No. 2.83 pp.

KING, J. R. and D. S. FARNER. 1961. Energy metabolism, thermoregulation, and body temperature. In: A. J. Marshall, ed., Biology and comparative physiology of birds. Vol. 2. New York: Academic Press. 468 pp.

KOSHKINA, T. V. and B. P. KISHCHINSKI. 1958. On food of the raven in the tundra of the Kola Peninsula and Seven Islands. Trudy Kandalakshfzapov, 1: 79-88. [In Russian].

PODKOVYRKIN, в. A. 1953. Winter food of Corvus corax behringianus on Shumshu Island (Curilian). Zoological Journal, Moscow, 32 (6): 1282-85. [In Russian].

SCHOLANDER, P. F., R. HOCK, V. WALTERS and L. IRVING. 1950. Adaptation to cold in arctic and tropical mammals and birds in relation to body temperature, insulation, and basal metabolism rate. Biological Bulletin, 99: 259-71.

sutton, G. M. 1932. The birds of Southampton Island. Carnegie Museum Memoirs. 12 (sect. 2): 1-275.

VEGHTE, J. H. and C. F. HERREID. 1965. Radiometric determinations of feather insulation and metabolism of arctic birds. Physiological Zoology, 38: 267-75. 